\title{
Effects of Fall Clipping or Burning on the Distribution of Chemical Constituents in Bluebunch Wheatgrass in Spring
}

\author{
W. WILLMS, A.W. BAILEY, A. MCLEAN, AND C. KALNIN
}

\begin{abstract}
We examined the effects of fall clipping or burning on chemical constituents and their distribution in bluebunch wheatgrass the following spring. The study was made in both a big sagebrushbluebunch wheatgrass and a Douglas fir-bluebunch wheatgrass community. The concentration of mineral constituents (nitrogen, phosphorus, calcium and magnesium) was lower while the concentration of fibrous constituents (acid detergent fiber, neutral detergent fiber and lignin) was higher in leafy material at the top of the plant. In the big sagebrush community, the differences among treatments were generally greater in the lower segments of plants. Generally, the mineral constituents increased while the fibrous constituents decreased from the control to the clipped to the burned treatment. The treatment effect was more variable in plants from the Douglas fir community.
\end{abstract}

Burning causes an increase in mineral constituents and digestibility (Daubenmire 1968; Pearson et al. 1972) whereas grazing does not appear to affect plant chemistry (Rickard et al. 1975; Willms et al. 1980). There is no information available on the vertical distribution of chemical constituents in bluebunch wheatgrass (Agropyron spicatum) and little information that compa res the effects of burning or grazing on plant chemistry. A study was made to determine the effects of fall clipping or burning on plant chemistry and on the distribution of chemical constituents within the plant.

\section{Site Description}

The study was conducted about $24 \mathrm{~km}$ northwest of Kamloops, British Columbia, in the big sagebrush (Artemisia tridentata)bluebunch wheatgrass and the Douglas fir (Pseudotsuga menziesii)-bluebunch wheatgrass communities. Their floristic composition has been described by McLean (1970) and Tisdale and McLean (1957). Annual precipitation at Kamloops in 1976 and 1977 was 29.8 and $30.3 \mathrm{~cm}$, respectively. The soils in the big sagebrush community are primarily Dark Brown Chernozems and in the Douglas fir community they are Eutric Brunisols (van Ryswyk et al. 1966). The elevation at the sites was $580 \mathrm{~m}$ and $760 \mathrm{~m}$ in the big sagebrush and Douglas fir communities, respectively.

\section{Methods}

Sites were selected in both the big sagebrush and Douglas fir communities. The fall treatments, representing no disturbance (control), clipping, or burning, were arranged in a $3 \times 3$ latin square. Plot dimensions were $4 \times 5 \mathrm{~m}$. The plots were burned with the aid of a propane torch in November, 1976, when the relative humidity was $60 \%$ and the average temperature $3^{\circ} \mathrm{C}$. Clipping was done at the same time. Standing litter ( \pm 1 SEm) was reduced from

W. Willms and A.W. Bailey are with the Department of Plant Science, University of Alberta, Edmonton, Alberta, T6G 2H1; and A. McLean and C. Kolnin are at the Agriculture Canada Research Station, Kamloops, B.C., V2B 8 A9.

The authors are indebted to Mr. R. Tucker and Mr. L. Stroesser for their technical assistance. Financial support was obtained through an Extramural Research Grant from Agriculture Canada.

Manuscript received September 14, 1979.
$30 \pm .7 \mathrm{~cm}$ to $5 \pm .2 \mathrm{~cm}$ by clipping and to $2 \pm .2 \mathrm{~cm}$ by burning.

Bluebunch wheatgrass plants were sampled the following May when in the boot stage. Samples from each community consisted of 54 plant representing 18 from each treatment. Sampling in the Douglas fir community was 1 week later than in the big sagebrush community to ensure a similar stage of growth.

Sampling was from $1-\mathrm{m}$ wide belts established parallel to the rows and $1 \mathrm{~m}$ from the lower edge. Plants were rejected from the sample if they had a circumference of less than $6 \mathrm{~cm}$ or they could not be distinguished from one another. The plant was defined as a group of associated tillers. Plant height was measured from the ground to the average length of the three longest tillers measured to the tips of vertically extended leaves. After measurement, the plants were clipped at $1.5 \mathrm{~cm}$ above ground level and individually bagged. Plants from each treatment were randomly sorted into three groups of six plants each. Final sample preparations were made by separating the green foliage from standing litter and dissecting the former into five segments of equal length. The segments, by percent height classes from the hase, were: (1) $0-20,(2)$ 21-40, (3) 41-60, (4) 61-80, and (5) 81-100. The individual segments were dried at $65^{\circ} \mathrm{C}$ to a constant weight.

Plant material in each group was composited by segment. Additional composition was required of the top two segments (4 and 5) to provide sufficient material for chemical analysis. In order to reduce the number of samples for chemical analysis, the first and third segments were further composited across the three groups in a treatment.

Samples were ground and analyzed for nitrogen, phosphorus, calcium, magnesium, acid detergent fiber (ADP), neutral detergent fiber (NDF) and lignin. Crude protein was determined by the standard A.O.A.C. (1975) methods. The NDF, ADF, and lignin were determined by the methods of Goering and van Soest (1970) and modified by Waldern (1971). Phosphorus was determined by the vandomolybdo color method of Jackson (1958). Calcium and magnesium were determined by atomic absorption spectrophotometric methods based on the techniques of Christian and Feldman (1970). All methods were standardized by analyzing (a) standard reference samples of known concentrations and (b) duplicate samples.

Statistical differences were analyzed using a 3-way analysis of variance model with Duncan's multiple range test. The main effects were treatments, segments (2nd and 4 th), and communities. The variability among groups was assumed to represent the experimental error.

\section{Results}

The chemical composition of bluebunch wheatgrass was affected by the vertical distribution in the plant (Table 1). Generally, the upper leafier segments were higher in mineral constituents and lower in fibrous constituents than the lower segments. Within segments, clipping or burning modified the chemical composition. In the big sagebrush community, burning resulted in more mineral 
Table 1. Effect of fall clipping or burning on the chemical constituents (\%) along a vertical gradient within bluebunch wheatgrass during May, 1977.

\begin{tabular}{|c|c|c|c|c|c|c|}
\hline \multirow[b]{2}{*}{ Segment* } & \multicolumn{3}{|c|}{ Big sagebrush } & \multicolumn{3}{|c|}{ Douglas fir } \\
\hline & Control & Clip & Burn & Control & Clip & Burn \\
\hline $\begin{array}{c}61-100 \\
41-60 \\
21-40 \\
0-20\end{array}$ & $\begin{array}{l}2.3 \mathrm{~d} \\
2.1^{* *} \\
1.6 \mathrm{ab} \\
.8\end{array}$ & $\begin{array}{l}2.3 \mathrm{~d} \\
2.0 \\
1.7 \mathrm{~b} \\
1.2\end{array}$ & $\begin{array}{l}\text { Nitrogen } \\
2.4 \mathrm{~d} \\
2.3 \\
1.9 \mathrm{c} \\
1.5\end{array}$ & $\begin{array}{l}2.3 \mathrm{~d} \\
2.0 \\
1.6 \mathrm{ab} \\
.9\end{array}$ & $\begin{array}{l}2.0 \mathrm{c} \\
1.8 \\
1.5 \mathrm{a} \\
.9\end{array}$ & $\begin{array}{l}2.4 \mathrm{~d} \\
1.9 \\
1.6 \mathrm{ab} \\
1.1\end{array}$ \\
\hline $\begin{array}{c}61-100 \\
41-60 \\
21-40 \\
0-20\end{array}$ & $\begin{array}{l}.18 \mathrm{ab} \\
.17 \\
.16 \mathrm{a} \\
.14\end{array}$ & $\begin{array}{l}.21 \mathrm{bc} \\
.16 \\
.18 \mathrm{ab} \\
.19\end{array}$ & $\begin{array}{c}\text { Calcium } \\
.21 b c \\
.20 \\
.22 \mathrm{~cd} \\
.21\end{array}$ & $\begin{array}{l}.29 \mathrm{e} \\
.25 \\
.22 \mathrm{~cd} \\
.21\end{array}$ & $\begin{array}{l}.29 \mathrm{e} \\
.23 \\
.23 \mathrm{~cd} \\
.19\end{array}$ & $\begin{array}{l}.38 \mathrm{f} \\
.25 \\
.26 \mathrm{de} \\
.24\end{array}$ \\
\hline $\begin{array}{c}61-100 \\
41-60 \\
21-40 \\
0-20\end{array}$ & $\begin{array}{l}.35 \mathrm{ed} \\
.29 \\
.27 \mathrm{a} \\
.22\end{array}$ & $\begin{array}{l}.34 \mathrm{ef} \\
.32 \\
.27 \mathrm{a} \\
.28\end{array}$ & $\begin{array}{c}\text { Phospho } \\
.36 \mathrm{fg} \\
.34 \\
.33 \mathrm{de} \\
.32\end{array}$ & $\begin{array}{l}.33 \mathrm{de} \\
.31 \\
.26 \mathrm{a} \\
.25\end{array}$ & $\begin{array}{l}.31 \mathrm{~cd} \\
.30 \\
.28 \mathrm{ab} \\
.23\end{array}$ & $\begin{array}{l}.37 \mathrm{~g} \\
.33 \\
.30 \mathrm{bc} \\
.28\end{array}$ \\
\hline $\begin{array}{c}61-100 \\
41-60 \\
21-40 \\
0-20\end{array}$ & $\begin{array}{l}.15 \mathrm{~cd} \\
.13 \\
.11 \mathrm{lab} \\
.09\end{array}$ & $\begin{array}{l}.15 \mathrm{~cd} \\
.11 \\
.12 \mathrm{~b} \\
.13\end{array}$ & $\begin{array}{c}\text { Magnesiu } \\
.14 \mathrm{c} \\
.14 \\
.15 \mathrm{~cd} \\
.17\end{array}$ & $\begin{array}{l}.14 c \\
.12 \\
.10 a \\
.10\end{array}$ & $\begin{array}{l}.15 \mathrm{~cd} \\
.13 \\
.12 \mathrm{~b} \\
.11\end{array}$ & $\begin{array}{l}.16 \mathrm{~d} \\
.11 \\
.11 \mathrm{ab} \\
.11\end{array}$ \\
\hline $\begin{array}{c}61-100 \\
41-60 \\
21-40 \\
0-20\end{array}$ & $\begin{array}{l}35.6 \mathrm{~cd} \\
38.7 \\
42.4 \mathrm{~g} \\
48.8\end{array}$ & $\begin{array}{l}35.2 \mathrm{bcd} \\
38.1 \\
40.9 \mathrm{~g} \\
44.9\end{array}$ & $\begin{array}{l}\text { ADF } \\
33.9 \mathrm{bc} \\
38.5 \\
37.0 \mathrm{de} \\
42.6\end{array}$ & $\begin{array}{l}34.4 b c \\
36.8 \\
39.3 f \\
43.9\end{array}$ & $\begin{array}{l}33.2 \mathrm{~b} \\
42.0 \\
41.7 \mathrm{~g} \\
44.5\end{array}$ & $\begin{array}{l}30.9 \mathrm{a} \\
35.3 \\
38.9 \mathrm{ef} \\
41.1\end{array}$ \\
\hline $\begin{array}{c}61-100 \\
41-60 \\
21-40 \\
0-20\end{array}$ & $\begin{array}{l}63.8 \mathrm{~d} \\
66.9 \\
71.3 \mathrm{f} \\
73.8\end{array}$ & $\begin{array}{l}59.6 \mathrm{~b} \\
66.6 \\
68.7 \mathrm{e} \\
71.2\end{array}$ & $\begin{array}{l}\text { NDF } \\
59.2 \mathrm{~b} \\
64.4 \\
63.7 \mathrm{~d} \\
66.9\end{array}$ & $\begin{array}{l}59.1 \mathrm{~b} \\
62.4 \\
64.1 \mathrm{~d} \\
67.8\end{array}$ & $\begin{array}{l}59.1 \mathrm{~b} \\
64.5 \\
63.1 \mathrm{~cd} \\
67.2\end{array}$ & $\begin{array}{l}55.7 \mathrm{a} \\
61.5 \\
63.3 \mathrm{~d} \\
65.1\end{array}$ \\
\hline $\begin{array}{c}61-100 \\
41-60 \\
21-40 \\
0-20\end{array}$ & $\begin{array}{l}2.3 \mathrm{a} \\
3.8 \\
6.8 \mathrm{c} \\
8.3\end{array}$ & $\begin{array}{l}3.2 \mathrm{ab} \\
1.4 \\
3.5 \mathrm{ab} \\
5.6\end{array}$ & $\begin{array}{l}\text { Lignin } \\
2.7 \mathrm{ab} \\
5.7 \\
3.5 \mathrm{ab} \\
5.2\end{array}$ & $\begin{array}{l}4.1 \mathrm{ab} \\
2.2 \\
3.6 \mathrm{ab} \\
4.9\end{array}$ & $\begin{array}{l}4.2 \mathrm{ab} \\
3.7 \\
2.9 \mathrm{ab} \\
4.4\end{array}$ & $\begin{array}{l}2.2 \mathrm{ab} \\
3.7 \\
2.7 \mathrm{ab} \\
3.7\end{array}$ \\
\hline
\end{tabular}

$* \%$ height from plant base.

** Mcans with no letter were not included in a statistical test for differences.

a-g Within a chemical constituents, means with the same letter do not differ significantly $(p>0.05)$.

but less ADF, NDF, and lignin in the lower segment. Only phosphorus and NDF in the top segment of burned plants differed significantly $(P<.05)$ from the control. The chemical composition of clipped plants was often intermediate between that of burned and control plants.

The treatment effect in the Douglas fir community produced similar trends as in the big sagebrush community. However, in the Douglas fir community, fewer significant differences, between the control and burned plants, occurred in the lower segment and more in the top segment. Calcium, phosphorus and magnesium were greater while ADF and NDF were lower in the top segment of burned plants. Only phosphorus increased with burning in the lower segment. Generally, for a treatment and segment, nitrogen, phosphorus, ADF and NDF were lower in the Douglas fir community while calcium was higher.

\section{Discussion}

Burning raised the mineral concentration and decreased the proportion of cell wall in the foliage. This effect may be partly the result of an enrichment of soil, by nutrients, on plant growth. Mes (1958, in Daubenmire, 1968) suggested that soil nutrients increase after burning as a result of an enrichment from ash, an increase in microbial activity releasing greater quantities of nutrients into the soil, and an increase in root activity causing greater uptake of nutrients. Uresk et al. (1975) reported that crude protein increased in bluebunch wheatgrass following burning.

The treatments affected not only the magnitude but also the distribution of chemical constituents within the plant. Removal of shade and shortened tillers in clipped and burned plants likely contributed to this effect.

Factors affecting the vertical distribution of chemical constituents are the length of internode on the culm, the variability among tiller lengths within a plant, and the stage of phenological development. The fibrous components, NDF, ADF and lignin, decrease from the bottom to the top of the plant in relation to decreasing tissue maturity and decreasing culm to leaf ratio. The secondary wall of the plant cell is formed after cell enlargement (Allinson 1969), hence formation is directly related to maturity which decreases with increasing plant height. The leaves have less fiber than the stem in Rhodes grass (Chloris gayana) and Pangola grass (Digitaria decumbens) (Goto and Minson 1977) and, presumably, in bluebunch wheatgrass. The culm to leaf ratio decreases from the lower to the upper plant segments as a result of shortening internodes. The method of dissection also contributed to this relationship. Since the leaves were held parallel to the culm, their proportion of dry matter increased and, at the top, was the only material represented. 


\section{References}

Allinson, D.W. 1969. Forage lignins and their relationship to nutritive value. Proc. National Conf. on Forage Qual. Eval. and Util. p. 51-59. A.0.A.C. 1975. Official methods of analysis of the Association of Official Analytical Chemists. Washington, D.C. p. 34, 927 and 928.

Christian, G.C., and F.J. Feldman. 1970. Atomic Absorption Spectroscopy. Applications in Agriculture, Biology and Medicine. Wiley Intersc. N.Y. 490 p.

Daubenmire, R. 1968. Ecology of fire in grasslands. Advanc. in Ecol. Res. 5:209-266.

Goering, H.K., and P.V. van Soest. 1970. Forage, fiber analysis-apparatus, reagents, procedures, and some applications. U.S. Dep. Agr., Washington, D.C., Publ. Jacket No. 387-598. 20 p.

Goto, I., and D.J. Minson. 1977. The potential digestibility of leaf and stem fractions of grasses. J. Agr. Sci. 89:143-149.

Jackson, M.L. 1958. Soil Chemical Analysis. Prentice-Hall, Englewood Cliffs. p. 151-154.

McLean, A. 1970. Plant communities of the Similkameen Valley, British Columbia, and their relationships to soils. Ecol. Monogr. 40:403-424.
Pearson, H.A., J.R. Davis, and G.H. Schubert. 1972. Effects of wildfire on timber and forage production in Arizona. J. Range Manage. 25:250-253.

Rickard, W.H., D.W. Uresk and J.F. Cline. 1975. Impact of cattle grazing on three perennial grasses in south-central Washington. J. Range Manage. 28:108-112.

Tisdale, E.W., and A. McLean. 1957. The Douglas fir zone of southern British Columbia. Ecol. Monogr. 27:247-266.

Uresk, D.W., J.F. Cline, and W.H. Rickard. 1975. Impact of wildfire on three perennial grasses in south-central Washington. J. Range Manage. 29:309-310.

van Ryswyk, A.L., A. McLean, and L.S. Marchand. 1966. The climate, native vegetation, and soils of some grasslands at different elevations in British Columbia. Can. J. Plant Sci. 46:35-49.

Waldern, D.E. 1971. A rapid micro-digestion procedure for neutral and acid detergent fiber. Can. J. Anim. Sci. 51:67-69.

Willms, W., A. McLean and C. Kalnin. 1980. The nutritive characteristics of important grasses on spring range in southern British Columbia. Can. J. of Plant Sci. (In press). 